Department of Biology and its Teaching Methods in Volodymyr Vynnychenko Central Ukrainian State Pedagogical University, Kropyvnytskyi

Circle of scientific interests: anatomy, physiology, urban flora, urban ecology, natural reserve resources of Ukraine, flora and fauna of Ukraine, plant and animal ecology.

NAIDONOVA Halyna Heorhiivna

Candidate of Pedagogical Sciences, Head of
Teaching Practice in Volodymyr Vynnychenko Central Ukrainian State Pedagogical University, Kropyvnytsky.

Circle of scientific interests: methods of teaching Biology, formation of the individual's ecological competence.

Стаття надійшла до редакиї 16.11.2020 р.

УДК 78.03(477); 37.036

DOI: $10.36550 / 2415-7988-2020-1-190-81-85$

BELIKOVA Valentina Venediktovna -

Candidate of Art History, Professor of the Department of Musicology, Instrumental and Choreographic Training of KryvyiRih State Pedagogical University, Member of the Union of Composers of Ukraine, Honored Worker of Culture of Ukraine ORCID:https://orcid.org/0000-0003-1151-7753 e-mail: etb@ukr.net

\title{
«MUSIC FRESCOES» BY BOHDANA FILTS AS A FACTOR OF DEVELOPMENT OF CREATIVE AND POTENTIAL FORCES OF THE MUSICIAN'S PERSONALITY
}

Formulation and justification of the relevance of the problem. At the turn of the XX-XXI centuries, humanistic and democratic trends in the development of Ukrainian society significantly aggravated the issue of professional development of future professionals in higher education.

Significant transformations in the economic, social, political life of the Ukrainian people form new worldviews of modern youth, intensify their search to improve the system of modern education in higher education.

Focusing on the needs of modern Ukrainian society, every young specialist comes to the conclusion - today everyone should be a high-profile specialist, and for this each specialist must develop one's creative potential. Only knowledge will help everyone to be a competitive specialist of high quality.

Analysis of recent research and publications. Familiarity with the scientific literature on the chosen topic suggests that many scientists do not have a single platform of views on awareness of the «creative potential of the individual» both in the definition of the essence of the concept and the process of highlighting the mechanism of creative potential of the future specialist.

It is important to develop the problem of creativity in the works of V. Andreev, L. Vygotsky, M. Goncharenko, V. Molyako, J. Ponomarev, V. Rybalko, S. Rubinstein and others.

The works of D. Bogoyavlenska, N. Kuzmina, D. Klein, A. Maslow, K. Rogers and others are devoted to the highlight in go the creative personality.

The purpose of the article explore creativity Bohdana Filts.

The main material of the study. Taking to attention that the purpose of the proposed study is to train future specialists in music education, we emphasize that a specialist in music education should be a high quality specialist in music disciplines. The specialist must have significant knowledge of the development of Ukrainian musical art. The latter determined the purpose of the presented scientific work - to highlight the importance of Ukrainian piano music by BohdanaFilts on the example of the instrumental cycle of the composer «Musical Frescoes».

Presenting main material. In 2015, the Drohobych publishing house «Posvit» published the following collection of piano miniatures by the famous Ukrainian composer, musicologist Bohdana Filts.

Bohdana Mykhailivna Filts is an Honored Art Worker of Ukraine (199), a laureate of the Prize named after M. Lysenko (1993), winner of the Prize named after V. Kosenko (2003), winner of the All-Ukrainian Competition of Composers «Spiritual Psalms of the Third Millennium» (2001), permanent scholarship holder of the Foundation "Ukraine of the XXI Century» (2000), holder of the Order of St. Barbara the Great Martyr, a member of the National Union of Composers of Ukraine since 1961, a member of the Music Foundation of Ukraine, a member of the creative commissions of the NUC, namely: musicology, aesthetic education, the selection committee of the Kyiv 
NUC Bohdana Mykhailivna often works as a member of the jury of various national and international competitions: young composers in Kyiv, children's choirs «Spring Bells» in Rivne, chairman of the jury of the international competition of academic art «Vivatmusica» in Nova Kakhovka, international festival of children's and youth choral art «Spring Kyiv Sings», a festival of sacred music on the basis of the children's choir school «Zorynka» in Ternopil. The artistis the author of more than 180 scientific publications, including eight monographs, more than 200 articles in encyclopedias, chapters in the History of Ukrainian music in six volumes, numerous articles in books, scientific collections, magazines, etc.

It should be noted that each collection of the composer is a bright long-awaited musical expression in the functioning Ukrainian piano literature and serves to be a witness of the past and present.

Being a person of extraordinary communication, high culture, openness and open generosity, Bohdana Mykhailivna always expressed her impressions of communication with young musicians in musical language.

The piano cycle «Musical Frescoes» is a brilliant evidence of the composer's communication with musicians, with whom she had contacts during music festivals, competitions, telephone conversations, even in the process of discussing her musical works.

Highlighting the development of genre diversity of instrumental music of the last years of the last century (miniatures, preludes, sketches, frescoes), Marina Rudyk emphasizes the fact that in the works of modern musicians of Ukraine quite often appear musical opuses whose names are associated with the word «frescoes». Highlighting the development of genre diversity of instrumental music of the last years of the last century (miniatures, preludes, sketches, frescoes), Marina Rudyk emphasizes the fact that in the works of modern musicians of Ukraine quite often appear musical opuses whose names are associated with the word «frescoes». For example: V. Bibik («Three frescoes for chamber orchestra», 1992), L. Dychko («Frescoes based on paintings by Kateryna Bilokur» for violin and organ and «Transcarpathian frescoes» for organ, 1986), B. Filtz («Musical frescoes for piano», 2015) and others.

It so happened that since the 90 s of the last century, the concert practice of pianists has stopped significantly. Philharmonics have reduced their activities. Tours of instrumentalists have become very rare. Popular
Romantic music (piano works by F. Liszt, S. Rachmaninoff, F. Chopin) was almost never performed. There was a certain confusion in the concert life. Composers began to actively «find» new formations in their musical treasuries.

There were works-memoirs about the past childhood (for example, Oleg Polevoy «At mum's fireplace»), piano pieces in which impressions from interesting creative travels were expressed (for example, a collection of bright piano pieces of O. Polevoy under the name «French notebook»). Contemporary Ukrainian composers have turned to ancient musical forms, confidently illuminating and updating them with today's content. For example, O. Nezhigay's piano suite «Everyday life of a young musician, or life as it is».

Ukrainian composers of modernity are especially active in the formation of ensemble piano music. For example, two plays for 4 hands by $\mathrm{O}$. Nezhygay «Melancholic Walt»z and «Let's Play Jazz». His stylistic arrangement for 8 hands of the Ukrainian folk song «Galya carries water». The vice-rector for educational work of the Dnepropetrovsk conservatory named after M. Glinka, Candidate of Art History S. Khananaev admitted that piano work by O. Nezhigay - is the result of «laboratory» experiments using various technical means, where the composer organically combines traditional intonation vocabulary with jazz metro-rhythmic techniques, «mixed» genre basis, musical semantics theatricality, assimilates various stylistic elements of other musical cultures» $[4$, p. 4].

Considering the functioning of modern Ukrainian piano music, it is necessary to emphasize the fact that despite the difficult economic and social living conditions of the current existence of Ukrainian society, musicians pay special attention to creating music especially for children, which demonstrates the great responsibility of Ukrainian artists for aesthetic and spiritual development of young musicians.Composers create music with a subtle sense of children's taste, their awareness of the world and their worldview.

In the context of what has been said, the music of Olena Honcharuk, whose musical works are a bright phenomenon in modern music, can also serve as a vivid confirmation of the above mentioned. Continuing the best traditions of famous Western European and classical composers of Ukrainian music, O. Honcharuk creates musical opuses of various structures (one-, two-, three-part musical compositions), which are set out in the favorite 
musical forms and genres of Romantic music, which impresses the audience and, at the same time, it possesses a simple texture of musical expression, a bright and expressive melodic line that reproduces a specific musical image. Thanks to the juicy support of the harmonious basis of the musical work, the musical miniature acquires an extremely brilliant sound and the work is perceived as a colorful bouquet of delicate wildflowers.

It goes about $\mathrm{O}$. Goncharuk's piano cycle «Rainbow», the appeal to which is not accidental. After all, in the title of each play (there are 7 of them) there is a modest hint - a word that characterizes and «reproduces» the necessary (according to the composer) color of this miniature. The latter helps the listener not only to perceive the wonderful music, but also to «see» the color «bloom» of each piece of the cycle.

Returning to the analysis of B.M. Filtz's musical work, it is efficient to join the opinion of the famous musicologist Maria Petrovna Zagaykevych that «there are works in Bohdana Filtz's piano works that attract attention with their unusual design and genre definition» $[3, \mathrm{p}$. 86-87].

These words completely belong to Bohdana Mykhailivna's collection «Musical Frescoes». Five piano pieces of the cycle were formed in different periods of years - from 2002 to 2015 of the new XXI century [1].

Time passed and the composer's musical frescoes gradually entered the musical life of young musicians. They began to be studied in the senior classes of the Music School, students of music colleges and art faculties of modern pedagogical universities.

The five piano pieces included in Bohdana Mykhailivna Filtz's cycle «Musical Frescoes» have classical structural schemes of well-known two-part and three-part musical forms. Each fresco is filled with unique figurative content. Each miniature is dedicated to a specific person, whose image left the composers with special feelings and vivid memories.

The first piece in the series «Dawn Fresc» (for Olenka) (2002) begins with a soft mp sound, the melodic line of which seems to sway on the rubato, bringing the development of the first sentence to a certain «forced» meaningful stop with the fermata. And the melodic stop was short. On the sound of $\mathrm{mf}$ and piumosso, the composer takes a new «breath» of the main melodic line, a kind of ending to the musical period, which clearly leads to the expected middle part (a tempo, cresc., accel.).

The middle part of the miniature is not perceived as a culmination - the victory of the previous emotional movement. The middle part ends in t. 15-16 on the dynamic cozy sound in pp. Septachords in arpeggiated presentation in the right hand have permanent supportby gamma-like chants in the left hand.The middle part ends with septachords (t. 16), which sound in the right and left hands in pp.

The second play «Evening Fresco» is dedicated to Volodymyr Grabovsky musicologist, culturologist, active promoter of musical creativity of Bohdana Mykhailivna Filts (since 1982), teacher of Drohobych State Music School.

Analyzing the second miniature of the cycle, it should be emphasized that the «Evening Fresco» continues to create a play in the style of Romantic music. According to the associate professor of Drohobych State Pedagogical University by I. Franko, a member of the National Union of Composers of Ukraine OleksandraNimilovych, the fresco «resembles lyrical-dramatic folk songs with a wavy unfolding of the thematic line» $[1, \mathrm{p} .5]$.

The development of the middle part of the second fresco, as in the previous play, leads the listener to the dynamics of pp (t. 32). The descending four-tactssecundo chants (t. 26-31) calm the general movement of the work, giving a deep meaning to the musical image of the «Evening Fresco».

The next third miniature of the series «Violet Fresco-Memorial» has two editions. The first was formed in 2008, the second appeared in 2014. «Violet Fresco-Memoir» is dedicated to the well-known Ukrainian performer of piano works by Bohdana Filts Maria Krushelnytska.

Bohdana Mykhailivna has a lot in common with the recognized pianist. First of all, the musical formations of the composer. We are talking about the editing and first performance by M. Krushelnytska the stage work by Bohdana Filts - «Kyiv Triptych» dedicated to the 1500th anniversary of the capital of Ukraine - Kyiv (1982).

The musical palette of «Violet FrescoMemoir» has a peculiar representing of the whole musical fabric of the work. The melodic line of the play has a singing character, set out in trios, which are used in almost every bar of the right hand. The middle part of the miniature (piumosso, marcato) sounds confident, affirming the grandeur and determination that fill the whole culminating episode, which gradually turns into a reprise (t. 14-21). It seems that the composer asserts the idea of musical language, which is one of the main means of communication in society.

The fourth miniature of the series 
«Christmas Fresco» (2013) is one of the most «dreamy» musical expressions of the composer. After all, during the Christmas holidays, everyone hopes for something unusual and special. The fresco is dedicated to the author of these words.

In the development of the melodic line of the fresco one can hear a familiar syncope (t. 2). And in the middle part of the work sounds especially emotional mood.

A year has passed! A person in the new year plans new successes and achievements. From t. 17 to t. 25 , the dynamic saturation is filled with $f$ and $f f-a$ sound that affirms Goodness, Peace and Happiness on earth. We think that such an idea can occur to anyone if they come to the Kiev-Pechersk Lavra every day at 12 o'clock in the afternoon. It is at this time that the Great Bell Tower spreads in Kyiv the «singing» of large and small bells about the happy well-being of all people.

It is also interesting that this fragment of the fresco is a special formation that echoes «Ostinato» - the first part of the «Kiev Triptych», formed to the 1500th anniversary of the capital of Ukraine, which symbolizes the epicenter of the Ukrainian state.

The fifth miniature of the series - «Spring Fresco» (2015) is dedicated to the associate professor of Drohobych State Pedagogical University by I. Franko, a member of the National Union of Composers of Ukraine, editor-compiler of many works of the Ukrainian composer, an active supporter of her music, Alexandra Nimilovich.

Each fresco of the cycle has its own figurative drama, outlined by the structure of the musical text chosen by the composer. The peculiarities of musical language are concentrated on the reproduction by the author of a specific personality, which became the "prototype» of the musical dedication of a certain fresco.Each fresco of the cycle has its own figurative drama, outlined by the structure of the musical text chosen by the composer. The peculiarities of musical language are concentrated on the reproduction by the author of a specific personality, which became the «prototype» of the musical dedication of a certain fresco.

The use of the same tempo in musical works (Allegretto) in the first and fifth miniatures emphasizes the meaningful completeness of piano formation as a holistic instrumental cycle.

The piano cycle «Musical Frescoes» is an example of glorifying the musical impressions of the artist, which remained from the meeting with people of previous years, who became her friends and good acquaintances, with whom Bohdana Mykhailivna had to work in the field of Ukrainian musical art.

Conclusions and prospects for further researches of direction. Summing up the review of «Musical Frescoes» by Bohdana Filts, we highlight the general features of the musical language of the composer's works that influence and develop the creative potential of the future specialist, namely:

- application of traditional forms of musical expression (two-part and three-part musical forms);

- use of foreslags, soft syncopated rhythmic shifts;

- use of sound comparisons of polar registers;

- combination of homophonic-harmonic and polyphonic textures of representing musical material;

- emphasizing with a dynamic line the wavy development of musical phrases of the work, etc.

The national character of the musical language of Bohdana Filts' works is manifested in the whole complex of expressive means of the composer's piano cycle, which provides a basis for the active use of the cycle in the educational process of various levels of musical institutions.

\section{BIBLIOGRAPHY}

1. Bohdana Filtz. Musical frescoes for piano: [Textbook] / Editor, comp. St. O. Nimilovich. Drohobych: Posvit, 2015. 16 p.

2. Grabovsky V. Bohdana Filtz in the Frankov region / Volodymyr Grabovsky // Musical Ukrainian Studies: modern dimension: Collection of scientific articles in honor of the Honored Artist of Ukraine, composer, candidate of art criticism Bohdana Filtz / Editor-compiler V. Kuzyk. Kyiv: IMPE named after M. Rylsky National Academy of Sciences of Ukraine, 2010. Issue. 5. P. 84.

3. Zagaykevich M. Bohdan Filtz. Creative portrait / Maria Zagaykevych. KyivTernopil: Aston, 2003. P. $86-87$.

4. Nezhigai O. Works for piano / OM Nezhigai // Works for piano. Vip. 2. Dnepropetrovsk, 2012. $64 \mathrm{p}$.

\section{REFERENSES}

1. Bohdana, Fil'ts. (2015). Muzychni fresky dlya fortepiano. [Musical frescoes for piano]. Drohobych.

2. Hrabovs'kyy, V. (2010). Bohdana Fil'ts u krayu Frankovim. [Bohdana Filtz in the Frankov region]. Kyiv.

3. Zahaykevych, M. Bohdana Fil'ts. (2003). Tvorchyy portret. [Creative portrait]. KyyivTernopil.

4. Nezhyhay, O. (2012). Tvory dlya fortepiano. [Works for piano]. Dnipropetrovs'.

ВІДОМОСТІ ПРО АВТОРА

БЕЛІКОВА Валентина Венедиктивна - 
кандидат мистецтвознавства, член Спілки композиторів України, заслужений працівник культури України, доцент кафедри музикознавства, інструментального та хореографічного навчання Державного педагогічного університету м. Кривий Ріг.

Наукові інтереси: вивчення проблем музики та сценічного мистецтва в Україні.
INFORMATION ABOUT THE AUTHOR

BELIKOVA Valentina Venediktivna Candidate of Art History, member of the Union of Composers of Ukraine, Honored Worker of Culture of Ukraine, KryvyiRih State Pedagogical University Associate Professor of Musicology, Instrumental and Choreographic Training.

Circle of scientific interests: studying the problems of music and performing arts in Ukraine.

Стаття надійшла до редакиії 18.10.2020 p.

УДК: 373.3.016:004-056.313

DOI: 10.36550/2415-7988-2020-1-190-85-90

ВДОВЕНКО Вікторія Віталіївна кандидат педагогічних наук, доцент кафедри методик дошкільної та початкової освіти Центральноукраїнського державного педагогічного університету імені Володимира Винниченка ORCID:https://orcid.org/0000-0002-0884-6209 e-mail: violeta_vv@ukr.net

КАШУБА Людмила Володимирівнакандидат педагогічних наук, доцент кафедри спеціальної освіти та здоров'я людини Центральноукраїнського державного педагогічного університету імені Володимира Винниченка ORCID:https://orcid.org/0000-0002-4569-3205 e-mail: kashubamila@gmail.com

\section{МЕТОДИЧНІ ОСНОВИ НАВЧАННЯ ЕЛЕМЕНТАМ КОМП'ЮТЕРНОЇ ГРАФІКИ МОЛОДШИХ ШКОЛЯРІВ ІЗ ЛЕГКИМ ПОРУШЕННЯМ ІНТЕЛЕКТУАЛЬНОГО РОЗВИТКУ}

\begin{tabular}{llr}
\multicolumn{1}{c}{ Постановка } & та & обгрунтування \\
актуальності & \multicolumn{1}{c}{ проблеми. } & Реформа \\
національної освіти в Україні & здійснюється в \\
умовах & глибокого & проникнення
\end{tabular} інформаційно-комунікаційних технологій (IКT) в усі сфери людської діяльності. ІКТ стають потужним показником науковотехнічного розвитку суспільства і суттєво впливають на зміст, форми і методи навчання. Хоча функції та можливості комп'ютера постійно змінюються та зростають, вони об'єктивно вплинули на те, що змінюється концептуальна роль самого комп'ютера: він стає засобом комунікації і отриманням інформації в будь-яких умовах. Особливого значення набуває проблема навчання молоді вмінням користуватися сучасними комп'ютерними засобами, орієнтуватися в їх функціональних можливостях, а також проблема підготовки молоді до активної, плідної життєдіяльності в інформаційному суспільстві.

Одним із завдань початкового курсу «Інформатики» $\epsilon$ формування початкових навичок інформаційної діяльності, зокрема, вмінь опрацьовувати графічну інформацію та розвиток об'єктно-орієнтованого мислення учнів [1].

Більшість учених-методистів впевнена, що запровадження комп'ютерізації шкіл буде спрямоване на вдосконалення організаційно-пізнавальної діяльності учнів 3 особливими потребами 3 основ наук, підвищення якості їхніх знань і корекцію вторинних відхилень у розвитку.

3 огляду на викладене, все більш актуальною стає проблема дослідження можливостей опанування комп'ютера учнями 3 різними фізичними та інтелектуальними порушеннями та запровадження комп'ютерних технологій у процес їх навчання. У нашому дослідженні розглянуто методичні основи навчання елементів комп'ютерної графіки в початковій школі 3 інклюзивною формою навчання.

Аналіз останніх досліджень i публікацій. Теоретичні дослідження впровадження пропедевтичного курсу інформатики в початкову школу здійснювали такі науковці, як В. О. Буцик, А. А. Дуванов, М. М. Левшин, Ю. А. Первін, І. М. Смирнова, Б. Хантер та ін. Проте у вказаних працях методика вивчення 